\title{
Prolactin protects against cytokine-induced beta-cell death by NFKB and JNK inhibition
}

\author{
Tarlliza R Nardelli', Emerielle C Vanzela', Keli C Benedicto', Flora Brozzi², André Fujita³, Alessandra K Cardozo², \\ Décio L Eizirik², Antonio C Boschero',** and Fernanda Ortis4,* \\ 'Department of Structural and Functional Biology, Laboratory of Endocrine Pancreas and Metabolism, Institute of Biology, University of Campinas \\ (UNICAMP), Campinas, Brazil \\ 2ULB Center for Diabetes Research, Medical Faculty, Université Libre de Bruxelles (ULB), Brussels, Belgium \\ ${ }^{3}$ Department of Computer Science, Institute of Mathematics and Statistics, University of São Paulo (USP), São Paulo, Brazil \\ ${ }^{4}$ Department of Cell and Developmental Biology, Institute of Biomedical Science (ICB), University of São Paulo (USP), São Paulo, Brazil
}

Correspondence should be addressed to F Ortis: fortis@usp.br

*(A C Boschero and $\mathrm{F}$ Ortis contributed equally to this work)

\begin{abstract}
Type 1 diabetes is caused by an autoimmune assault that induces progressive beta-cell dysfunction and dead. Pro-inflammatory cytokines, such as interleukin 1 beta (IL1B), tumor necrosis factor (TNF) and interferon gamma (IFNG) contribute for beta-cell death, which involves the activation of the nuclear factor kappa B (NFKB) and c- Jun N-terminal kinase (JNK). Prolactin (PRL), a physiological mediator for beta-cell proliferation, was shown to protect beta cells against cytokines pro-apoptotic effects. We presently investigated the mechanisms involved in the protective effects of prolactin against cytokine-induced beta-cell death. The findings obtained indicate that STAT3 activation is involved in the anti-apoptotic role of PRL in rat beta cells. PRL prevents the activation of JNK via AKT and promotes a shift from expression of pro- to anti-apoptotic proteins downstream of the JNK cascade. Furthermore, PRL partially prevents the activation of $\mathrm{NF \kappa B}$ and the transcription of its target genes $I k B a$, Fas, Mcp 1, A20 and Cxc/10 and also decreases NO production. On the other hand, the pro-survival effects of PRL do not involve modulation of cytokine-induced endoplasmic reticulum stress. These results suggest that the beneficial effects of PRL in beta cells involve augmentation of antiapoptotic mechanisms and, at the same time, reduction of pro-apoptotic effectors, rendering beta cells better prepared to deal with inflammatory insults. The better understanding of the pro-survival mechanisms modulated by PRL in beta cells can provide tools to prevent cell demise during an autoimmune attack or following islet transplantation.
\end{abstract}

Key Words
NFkB
pancreatic beta cells
pro-inflammatory
cytokines
- prolactin
- STAT3

\section{Introduction}

Type 1 diabetes (T1D) is caused by an autoimmune assault that induces progressive beta-cell dysfunction and apoptosis, consequently impairing insulin secretion. During insulitis, pro-inflammatory cytokines such as interleukin 1 beta (IL1B), tumor necrosis factor (TNF) and interferon gamma (IFNG), contribute to beta-cell failure and death. At the time of diagnosis, it has been estimated a $70-80 \%$ loss of beta-cell functional mass 
(Kukreja \& Maclaren 1999, Noble 2015). Beta-cell loss in T1D is probably slow and progressive, suggesting that preventing beta-cell death is possible.

It has been previously shown that prolactin (PRL) has beneficial effects on pancreatic islets during pregnancy or following in vitro exposure (Boschero et al. 1993, Crepaldi etal. 1997, Cunha etal.2007). Activation of the PRL receptor is important to increase beta-cell mass and maintain physiological glucose tolerance during pregnancy (Amaral et al. 2004), and decrease the expression of pro-apoptotic genes (Bordin et al. 2004). These biological effects require the participation of receptor-associated kinases, mainly through the JAK/STAT pathway (Bole-Feysot et al. 1998).

PRL protects human islets against inflammatory cytokine-mediated apoptosis, and this seems to be at least in part mediated by inhibiting the cell death pathways controlled by the pro-apoptotic BCL2 family members (Terra et al. 2011). The members of this family of proteins are grouped into the following three categories: prosurvival (BCL2, BCLxl, MCL1, BCLw and A1), proapoptotic (BAX, BAK and BOK) and BH3-only proteins, which are also pro-apoptotic and divided in sensitizers (DP5, BIK, NOXA and BAD) and activators (BIM, PUMA and BID) (Kim et al. 2006). When the expression of BH3only sensitizers increases, they directly bind and inhibit the pro-survival members, releasing the activators. Once free, the activators bind and activate the pro-death members to form pores in the mitochondria, inducing cytochrome c release (Kim et al. 2006). In beta cells, JNK is also involved in the activation of the mitochondrial pathway of apoptosis through cJUN phosphorylation, DP5 expression and downregulation of MCL1 (Gurzov et al. 2008, 2009, Allagnat et al. 2011).

Many of the genes modified by cytokines in beta cells are regulated by the transcription factor nuclear factor kappa B (NFkB), which, directly or indirectly, controls the expression of proteins involved in the endoplasmic reticulum (ER) stress (via NO production in the case of rat beta cells) and cell death (Cardozo et al. 2001a, Darville et al. 2004). The canonical process of NFkB activation is initiated by the phosphorylation of the inhibitor of kappa B $(I k B)$, leading to ubiquitination and proteasome degradation. This allows the nuclear translocation of $\mathrm{NF \kappa B}$ and increases the transcription of target genes (Chiu et al. 2009). The transcriptional activity of NFkB can also be regulated by post-translational mechanisms (Vermeulen et al. 2002, Hayden \& Ghosh 2008). Moreover, proinflammatory cytokines lead to a decreased expression of the PRL receptor, reducing the capacity of the beta-cell to recover after an autoimmune assault (Kutlu et al. 2003,
Ortis et al. 2010), but the nature of the crosstalk between PRL signaling and the inflammatory response regulated by NFkB (or other pathways) induced by cytokines remain to be clarified.

We have presently identified novel specific targets of PRL in beta cells in the context of inflammation. The findings obtained indicate that PRL exerts an antiapoptotic role in rat beta cells exposed to pro-inflammatory cytokines potentially through STAT3. PRL induces AKT phosphorylation and consequentially prevents the cytokine-dependent JNK activation, promoting the differential expression of anti- and pro-apoptotic proteins downstream of the JNK cascade. Moreover, PRL partially prevents the activation of $\mathrm{NF \kappa B}$ and the transcription of its target genes IkBa, Fas, Mcp1, A20 and Cxcl10.

\section{Materials and methods}

\section{Culture of rat islets and INS-1E cells}

Wistar rats were used according to the rules of the Brazilian Regulations for Animal Care with approval of the Ethical Committee for Animal Experiments of the UNICAMP, Campinas, Brazil. Pancreatic islets were isolated from adult female Wistar rats as described (Vanzela et al. 2010). The islets were maintained in RPMI-1640 culture medium containing $5.6 \mathrm{mmol} / \mathrm{L}$ glucose and $10 \% \mathrm{v} / \mathrm{v}$ of fetal bovine serum (FBS) for $24 \mathrm{~h}$ prior to treatment. Insulin-producing INS-1E cells (Asfari et al. 1992, Janjic et al. 1999), a kind gift from Prof. C Wolheim (Centre Médical Universitaire, Geneva, Switzerland), were cultured in RPMI-1640 medium and supplemented with $5 \% \mathrm{v} / \mathrm{v}$ of FBS, HEPES $10 \mathrm{mmol} / \mathrm{L}$, penicillin $100 \mathrm{U} / \mathrm{mL}$, streptomycin $100 \mu \mathrm{g} /$ $\mathrm{mL}$, sodium pyruvate $1 \mathrm{mmol} / \mathrm{L}$ and 2-mercaptoethanol $50 \mu \mathrm{mol} / \mathrm{L}$ in the presence of $11 \mathrm{mmol} / \mathrm{L}$ glucose.

\section{Cell treatment and NO measurement}

Rat islets were cultured in RPMI medium; containing $5.6 \mathrm{mmol} / \mathrm{L}$ glucose, $1 \% \mathrm{v} / \mathrm{v}$ of FBS and $5 \% \mathrm{w} / \mathrm{v}$ of BSA, with $0.5 \mu \mathrm{g} / \mathrm{mL}$ of PRL or vehicle $(0.01 \mathrm{mmol} / \mathrm{L} \mathrm{NaHCO}+0.3 \%$ $\mathrm{w} / \mathrm{v} \mathrm{BSA}$ ) for $24 \mathrm{~h}$, and then challenged with $10 \mathrm{U} / \mathrm{mL}$ of human recombinant IL1B (R\&D Systems) and $1000 \mathrm{U} / \mathrm{mL}$ of rat recombinant IFNG (R\&D Systems) for additional $48 \mathrm{~h}$. For the treatment of INS-1E cells with PRL and cytokines, cells were maintained in a medium with $1 \%$ $\mathrm{w} / \mathrm{v}$ of BSA and $5.6 \mathrm{mmol} / \mathrm{L}$ glucose without FBS. The experiments were performed after $24 \mathrm{~h}$ pre-treatment with PRL $(0.5 \mu \mathrm{g} / \mathrm{mL})$ or vehicle and 24 -h subsequent exposure to $10 \mathrm{U} / \mathrm{mL}$ of human recombinant IL1B (R\&D Systems) 
or $1600 \mathrm{U} / \mathrm{mL}$ of rat recombinant TNF (Invitrogen) combined with $100 \mathrm{U} / \mathrm{mL}$ of rat recombinant IFNG (R\&D Systems). PRL or vehicle were also kept in the medium during cytokine exposure in both INS-1E and rat islets. INS-1E cells exposed to IL1B + IFNG were also used in the time course studies. Nitric oxide (NO) was measured as accumulated nitrite in the medium by the Griess reaction (Green et al. 1982, Schulz et al. 1999). The Wortmannin (Sigma-Aldrich), a specific inhibitor of PI3 kinase, used to decrease the phosphorylation of AKT, was dissolved in DMSO and used in INS-1E cells at $250 \mathrm{nmol} / \mathrm{L}$, based on dose-response experiments (data not shown).

\section{Assessment of apoptosis}

The percentage of apoptotic cells was determined by the following methods: (A) after $15 \mathrm{~min}$ incubation with the DNA-binding dyes Hoechst $33342(5 \mu \mathrm{g} / \mathrm{mL}$; Sigma-Aldrich) and propidium iodide $(5 \mu \mathrm{g} / \mathrm{mL}$; SigmaAldrich), the viable and apoptotic nuclei were counted by two independent observers, in which one of them was unaware of sample identity (Ortis et al. 2006); (B) by the Guava Nexin Reagent kit (Merck Millipore), in which cells positive for annexin $\mathrm{V}$ were detected by flow cytometry (Guava easyCyte 8HT) according to the manufacturer's protocol and (C) by Western blot for cleaved caspase 3 (see details below). The figures were expressed by control values, equal to one, to better visualize the cell death induction.

\section{Western blot assay}

After cell culture and treatment, the cells were lysed using a Laemmli sample buffer. The total protein was fractioned in an 8-12\% SDS-PAGE and transferred to a nitrocellulose membrane. Immunoblot analysis was performed using the specific antibodies for the protein of interest: phosphoSAPK/JNK (Thr183/Tyr185), phospho-c-JUN (Ser63), cleaved CASPASE 3, phospho-STAT3, STAT3, PUMA (Cell Signaling); iNOS (Abcam); phospho-AKT (ser473), phospho-AKT (thr308) and IKBA (Santa Cruz), followed by the incubation with the appropriate horseradish peroxidase-conjugated secondary antibody (Thermo Scientific). The protein intensity was detected by an ImageQuant LAS 4000 (GE Healthcare Bio-Sciences) after the chemiluminescent reaction with the SuperSignal West Femto Chemiluminescent Substrate (Thermo Scientific), according to the manufacturer instructions. The intensity values for the proteins were quantified using ImageQuant TL 7.0 Software (GE Healthcare Bio-Sciences), corrected by the housekeeping protein alpha tubulin (aTubulin) (Sigma-Aldrich) to confirm similar protein loading and normalized by the control condition. Notice that in this case, the control condition is considered to be one. When the protein is not induced in the control, no normalization was done (to avoid division by zero).

\section{mRNA extraction and real time RT-PCR (qRT-PCR)}

Poly (A) + mRNA was isolated from the treated cells using the Dynabeads mRNA DIRECTTM kit (Invitrogen). A constant amount of the purified mRNA was reversetranscribed using $50 \mathrm{U} \mathrm{MuLV}$ reverse transcriptase (Invitrogen) at $42^{\circ} \mathrm{C}$ for $60 \mathrm{~min}$ in a reaction containing $1 \times$ Buffer $\left(16 \mathrm{mmol} / \mathrm{L}\left(\mathrm{NH}_{4}\right)_{2} \mathrm{SO}_{4}, 67 \mathrm{mmol} / \mathrm{L}\right.$ Tris- $\mathrm{HCl}$ $\mathrm{pH} 8.8$ (at $25^{\circ} \mathrm{C}$ ) and $0.01 \%$ Tween 20), $5 \mathrm{mmol} / \mathrm{L} \mathrm{MgCl}_{2}$ (GeneCraft, Cologne, Germany), $2 \mathrm{mmol} / \mathrm{L}$ dNTP mix (Eurogentec, Seraing, Belgium), $2.5 \mu \mathrm{mol} / \mathrm{L}$ random primers and $20 \mathrm{U}$ RNAse inhibitor (Invitrogen). The realtime RT-PCR amplification reactions were performed using an iQ SYBR Green Supermix on Rotor-Gene Q (Qiagen), and the concentration of the gene of interest was calculated as copies per microliter using a standard curve. Gene expression values in INS-1E cells were corrected by the housekeeping gene Gapdh.

\section{Promoter reporter assay}

Cells were co-transfected using Lipofectamine 2000 (Invitrogen) with the pRL-CMV internal control encoding Renilla (Promega) and the pNFkB-Luciferase (BD Biosciences) (Ortis et al. 2008). After transfection (16h), the cells were treated as described earlier. The luciferase activity was analyzed using the Dual-Luciferase Reporter Assay System kit (Promega), according to the manufacturer instructions. The luciferase activity values were corrected by the values of the internal control pRL-CMV of each experiment.

\section{Small interfering RNA (siRNA) treatment}

Two different siRNAs against STAT3 (Sigma-Aldrich) were used to knock down the expression of the target gene. Allstars Negative Control siRNA (Qiagen) was used as a negative control. After overnight incubation with $30 \mathrm{nmol} / \mathrm{L}$ of siRNA using $1 \mu \mathrm{L}$ per well Lipofectamine RNAiMAX, lipid reagent (Invitrogen), the transfection medium was replaced by a regular culture medium for cell recovery. After $48 \mathrm{~h}$, the cells were exposed to treatment as described earlier. 


\section{Statistical analysis}

For expression comparison analysis, we used a paired $t$-test on the log-transformed data. A nominal $P$-value threshold (without correction for multiple tests) of 0.05 was considered to be statistically significant. Notice that since we applied the paired $t$-test on the log-transformed data, the effects of data normalization by the control condition is only for visual inspection. For the statistical analysis, the normalization has no effect because the data are log transformed. For illustration, consider that we would like to test whether (with PRL/control)/(without PRL/control) $=1$. By applying the log-transform, it is equivalent to test log (with PRL) $=\log$ (without PRL). It can be tested by a $t$-test because the logarithm is a monotonic transformation. The choice for the $t$-test rather than the usual factorial analysis of variance is because of issues of heteroskedasticity.

\section{Results}

\section{PRL prevents the apoptosis induced by pro- inflammatory cytokines}

Exposure of INS-1E cells for $24 \mathrm{~h}$ to cytokines increased the prevalence of apoptotic cells (Cardozo et al. 2001a,
Ortis et al. 2006, Allagnat et al. 2011), which is confirmed by three different methods (Fig. 1A, B and C). The pretreatment of these cells with PRL prevented cell death (Fig. 1A and B) and partially the cleavage of CASPASE 3 (Fig. 1C), which was still observed after $48 \mathrm{~h}$ of cytokines treatment. Of note, the beneficial effect of PRL was also observed in control cells that were not exposed to cytokines (Fig. 1A and B). Because the results were similar for both cytokine combinations, the subsequent experiments were performed using only IL1B+IFNG. Importantly, the pretreatment with PRL was also efficient in preventing (by $\sim 40 \%$ ) the activation of CASPASE 3 induced by cytokines in rat islets (Fig. 1D).

\section{STAT3 potentially mediates the beneficial effects of PRL}

We next evaluated the impact of PRL on the expression of STAT3 (Bordin et al. 2004, Anhe et al. 2007) and its phosphorylation (DaSilva et al. 1996). The STAT3 phosphorylation was induced by PRL treatment as observed after $15 \mathrm{~min}$ to $8 \mathrm{~h}$ of PRL exposure (Fig. 2A and B), confirming the regulatory role of PRL on STAT3 activation. To test whether STAT3 was involved in the
A

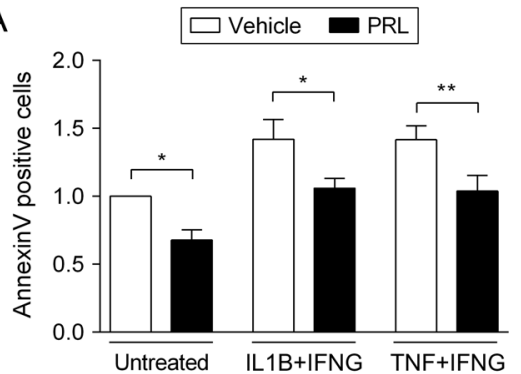

C
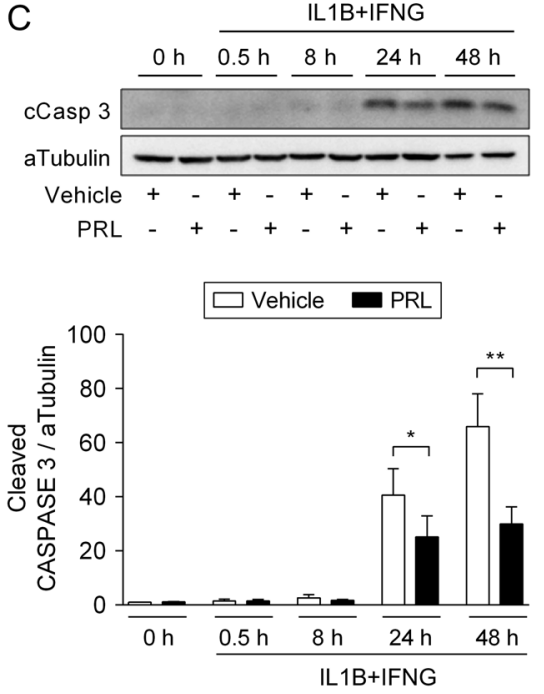

B

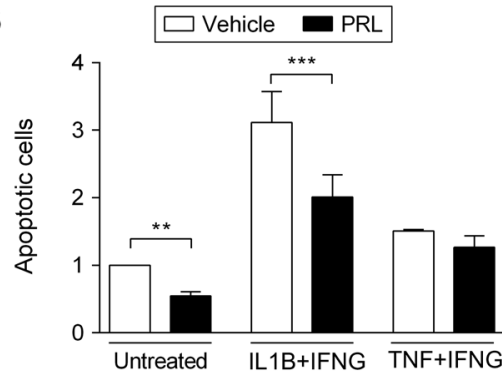

D
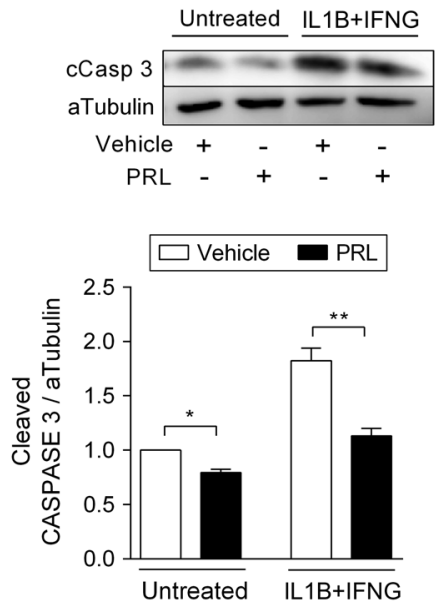

\section{Figure 1}

PRL prevents apoptosis induced by proinflammatory cytokines in rat islets and INS-1E cells. INS-1E cells (A, B and C) or rat islets (D) were pre-cultured with a vehicle or PRL and then treated with IL1B or TNF in combination with IFNG for $24 \mathrm{~h}$ (INS-1E), $48 \mathrm{~h}$ (rat islets) or for the time point indicated in the figure. (A) Apoptosis determined by percentage of Annexin V-positive cells of 5 independent experiments, normalized for the respective control (considered as one), showed as mean \pm S.E.M. (B) Percentage of apoptotic cells determined by DNA-binding dyes Hoechst and propidium iodide, $n=2$ (TNF) to $n=7$, normalized for the respective control (considered as one), showed as mean \pm S.E.M. (C and D) Western blot for INS-1E cells (C) and rat islets (D) cleaved CASPASE 3. One representative Western blot of 3 (islets) to 5 (INS-1E) independent experiments is shown, graphs showed the values corrected by aTubulin and normalized for the respective control values (considered as one). Results are means \pm S.E.M. ${ }^{*} P \leq 0.05, * * P<0.01$ or $* * * P<0.001$ for log-transformed paired $t$-test of vehicle vs PRL. 
beneficial effects of PRL, two specific siRNAs (siSTAT3-1 and siSTAT3-2) were used to suppress STAT3 in INS-1E cells. The first siRNA was not able to significantly decrease expression of STAT3 (Fig. 2C and D), with no significant effect on cell viability (Fig. 2E). A better knockdown (KD) (60\% inhibition) was observed with the second siRNA, namely siSTAT3-2 (Fig. 2C and D), which abolished the prevention of apoptosis induced by PRL following exposure to cytokines (Fig. 2E).

\section{PRL modifies the activation of JNK and decreases cJUN-dependent Dp5 expression}

One of the mechanisms by which cytokines contribute to beta-cell apoptosis is via JNK activation (Ammendrup et al. 2000), and consequent JNK/cJUN-dependent Dp5 expression (Gurzov et al. 2009). Pre-treatment with PRL modified the pattern of JNK activation after exposure to cytokines in the continuous presence of PRL, with an early increase in the phosphorylation of JNK after $30 \mathrm{~min}$, followed by a decrease in JNK phosphorylation after 8 and $24 \mathrm{~h}$, compared with IL1B + IFNG alone (Fig. 3A). In addition, INS-1E cells pre-exposed to PRL and then treated with cytokines for 8 or $24 \mathrm{~h}$, in the continuous presence of PRL, displayed reduced phosphorylation of cJUN (8h) (Fig. 3B), a downstream indicator of JNK activity, and $D p 5$ expression (24h) (Fig. 3C), suggesting that PRL-induced inhibition of JNK phosphorylation plays a key role in preventing beta-cell death.

\section{PRL regulates the expression of pro- and anti-apoptotic BCL2 family members}

We next evaluated the involvement of PRL in modulating the pro-death BH3-only proteins BIM and PUMA, known to be activated downstream of $D p 5$ (Gurzov et al. 2009, Gurzov \& Eizirik 2011). After $24 \mathrm{~h}$ of treatment, IL1B+IFNG increased Bim (Fig. 4A) and Puma mRNA (Fig. 4C) and PUMA protein expression (Fig. 4D and E). Although PRL did not prevent cytokine-induced total Bim mRNA expression (Fig. 4A), it decreased the expression of its most pro-apoptotic isoform, namely Bim small (BimS), in untreated condition and marginally following cytokine condition (Fig. 4B). PRL also decreased cytokine-mediated PUMA expression at the mRNA
A

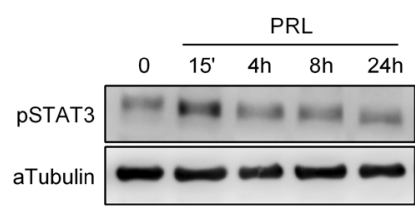

C

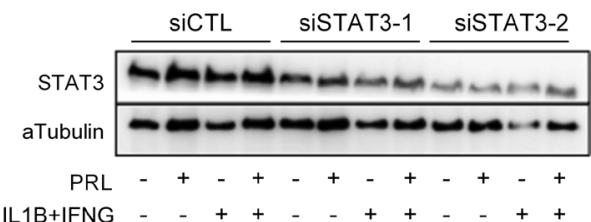

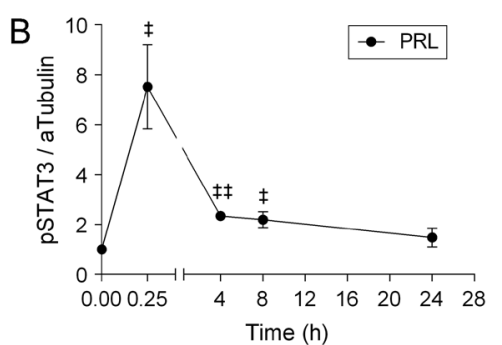

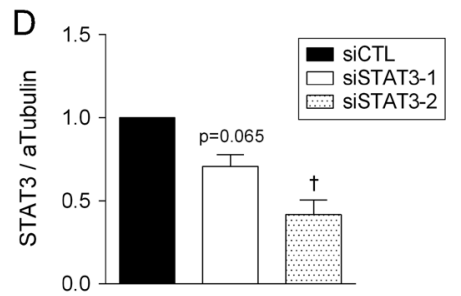

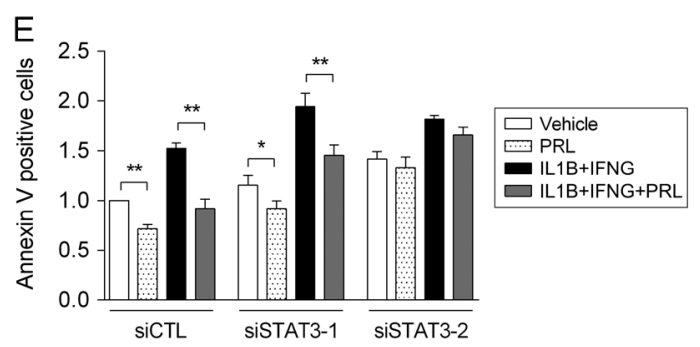

Figure 2

The STAT3 pathway is involved in PRL protective effects against cytokine-induced apoptosis. (A and $B$ ) INS-1E cells were treated with PRL for the time points indicated in the figure. Protein cell lysates were used in Western blot for phosphorylated STAT3 (pSTAT3) and aTubulin. (A) One representative Western blot of 3 independent experiments. (B) Optical density measurements of the blots corrected by aTubulin are expressed as mean \pm S.E.M. and normalized by the control value in each experiment (considered as one). ${ }^{\ddagger} P<0.05$ or ${ }^{\ddagger \ddagger} P<0.01$ for log-transformed paired $t$-test of each time point vs control (time point zero). (C, D and E) INS-1E cells were transfected overnight with two specific siRNAs for STAT3 (siSTAT3-1 and siSTAT3-2) or a control siRNA (siCTL). $48 \mathrm{~h}$ after transfection, cells were treated for $24 \mathrm{~h}$ with vehicle or PRL, then with IL1B + IFNG for additional $24 \mathrm{~h}$. ( $C$ and D) Protein cell lysates were used in Western blot for STAT3 and aTubulin. (C) One representative Western blot of 3 independent experiments. (D) Optical density measurements of bands corresponding to STAT3 corrected by aTubulin and normalized by the control value in each experiment (considered as one) are expressed as mean \pm S.E.M. ${ }^{\dagger} P<0.05$ for log-transformed paired $t$-test of each siRNA vs siCTL. (E) Apoptosis determined by percentage of annexin $\mathrm{V}$ positive cells of 4 independent experiments, results were normalized by the control value in each experiment (considered as one). Data are means \pm S.E.M. ${ }^{*} P \leq 0.05$ or $\star * P<0.01$ for log-transformed paired $t$-test of vehicle vs PRL. 
A
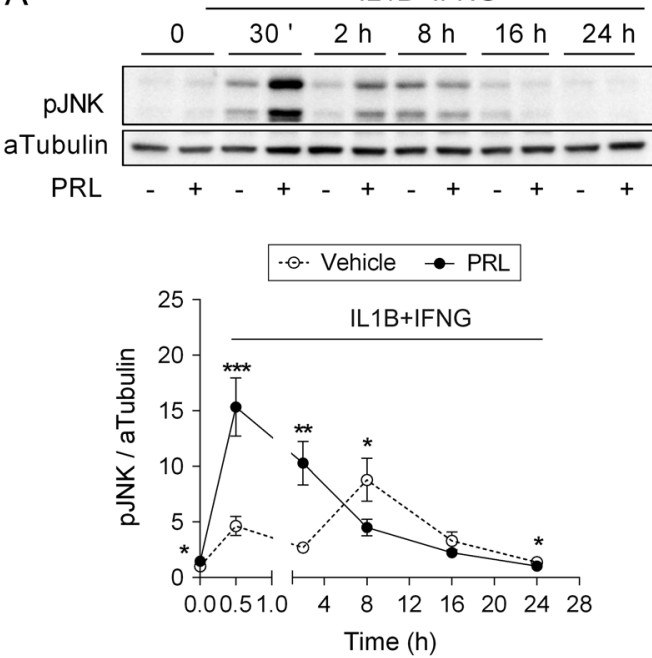

B

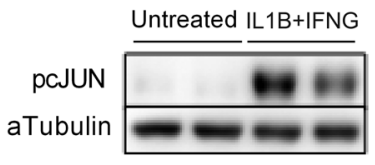

PRL

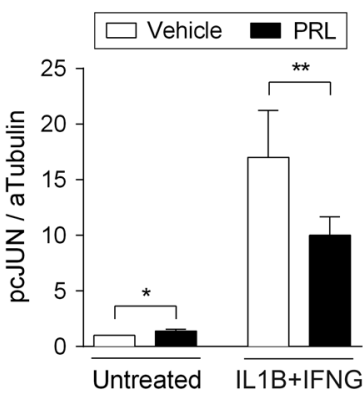

Figure 3

PRL modulates the activation of JNK/CJUNdependent $D p 5$ expression in INS-1E cells. INS-1E cells were treated for $24 \mathrm{~h}$ with PRL or vehicle and then with IL1B + IFNG for $8 \mathrm{~h}$ (B) or $24 \mathrm{~h}$ (C) or for the time points indicated in the figure $(A)$ in the continuous presence of PRL. Protein cell lysates were used in Western blot for phosphorylated JNK (pJNK), phosphorylated cJUN (pcJUN) and aTubulin. One representative Western blot of 7-8 independent experiments and optical density measurements of the blots for pJNK (A) and pcJUN (B), corrected by aTubulin and normalized by the control in each experiment (considered as one) are expressed as mean \pm s.E.M. (C) The expression of $D p 5$ was assessed in 4 independent experiments by qRT-PCR, corrected by the housekeeping gene Gapdh and expressed as mean \pm s.E.M. ${ }^{*} P \leq 0.05, * * P<0.01$ or $* * * P<0.001$ for log-transformed paired $t$-test of vehicle vs PRL at the same time point.
(Fig. 4C) and at protein levels (Fig. 4D and E). Importantly, PRL alone increased the expression of the pro-survival BCL-2 family protein BCLxl in a time-dependent manner and also increased (30\%) the expression of this protein after $8 \mathrm{~h}$ of exposure to cytokines compared with cells treated with IL1B+IFNG alone (data not shown).

\section{PRL-decreased JNK activation is dependent of AKT}

PRL induces activation of AKT in pancreatic beta cells (Amaral et al. 2004), which was confirmed in our model by the observed increased phosphorylation of both serine and threonine residues of AKT in PRL-treated INS-1E cells (Fig. 5A and B). Cytokines have been described to impair the signal transduction of this pro-survival pathway (Storling et al. 2005). In line with this, after $30 \mathrm{~min}$ of IL1B+IFNG exposure there was a clear decrease in the phosphorylation of AKT at serine 473 in both vehicleand PRL-treated cells (Fig. 5A). At later time points, however, PRL was able to maintain and even increase AKT phosphorylation in both residues in spite of the continuous presence of cytokines (Fig. $5 \mathrm{~A}$ and B), which
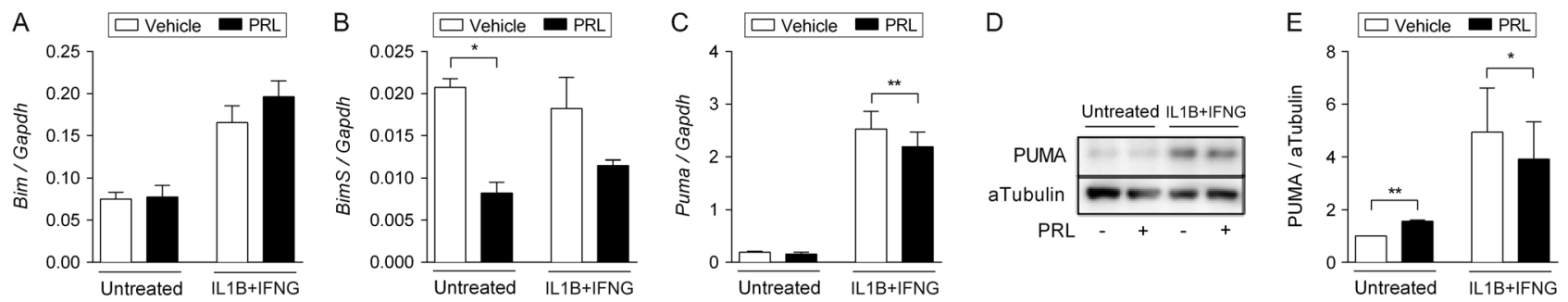

Figure 4

PRL downregulates the expression of pro-apoptotic BCL2 family members. INS-1E cells were pretreated for $24 \mathrm{~h}$ with vehicle or PRL and then with IL1B + IFNG for additional $24 \mathrm{~h}$ in the continuous presence of PRL. The expression of (A): Bim, (B): Bim small (BimS) and (C): Puma was assessed by qRT-PCR and corrected by the housekeeping gene Gapdh. The data represent the means \pm s.E.M. of 4 independent experiments. (D and E) PUMA expression was also analyzed by Western blot. (D) One representative Western blot of 4 independent experiments, (E) optical density measurements of bands corresponding to PUMA corrected by aTubulin and normalized by the control in each experiment (considered as one) are expressed as mean \pm S.E.M. $* P<0.05$ or $* * P<0.01$ for log-transformed paired $t$-test of vehicle vs PRL. 
A
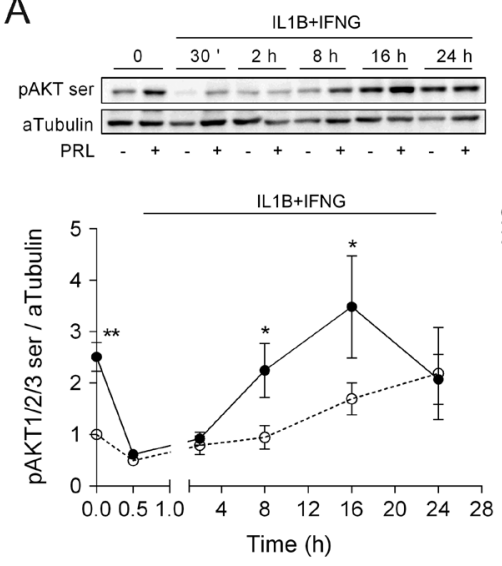

C
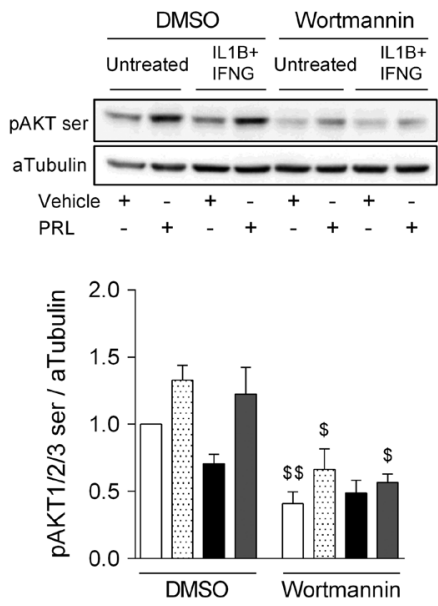

F

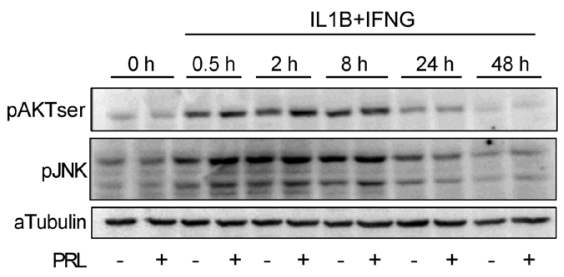

B

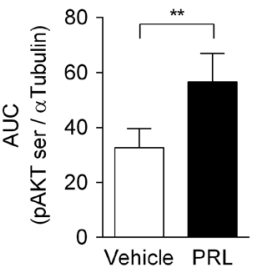

$-\odot \cdot$ Vehicle
- PRL
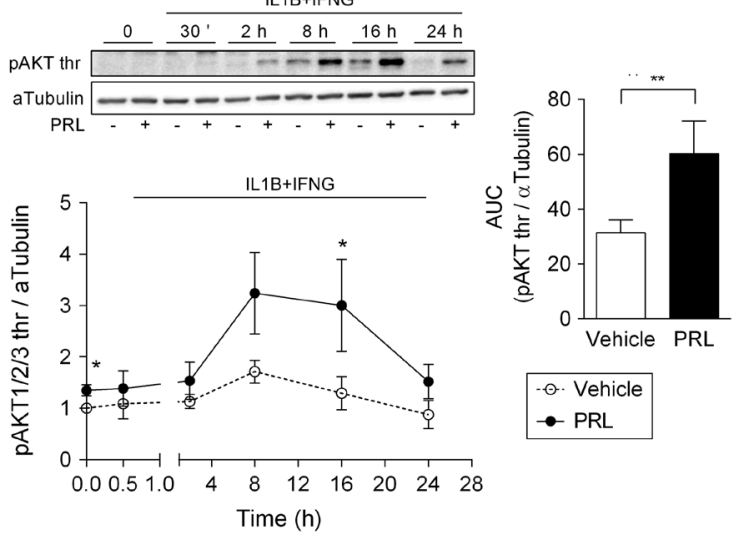

$\rightarrow$ PRL
D
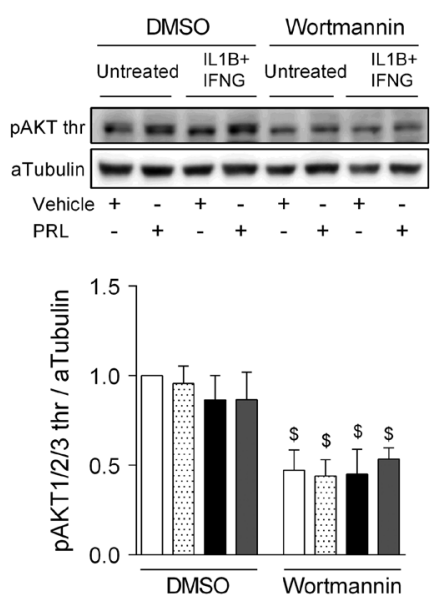

G

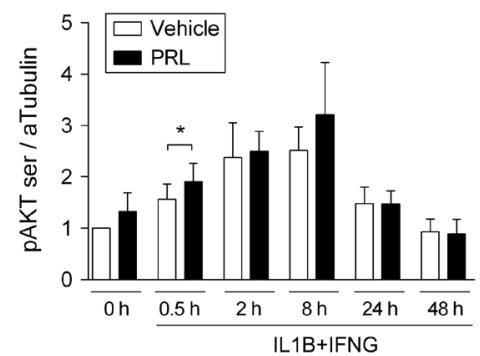

E
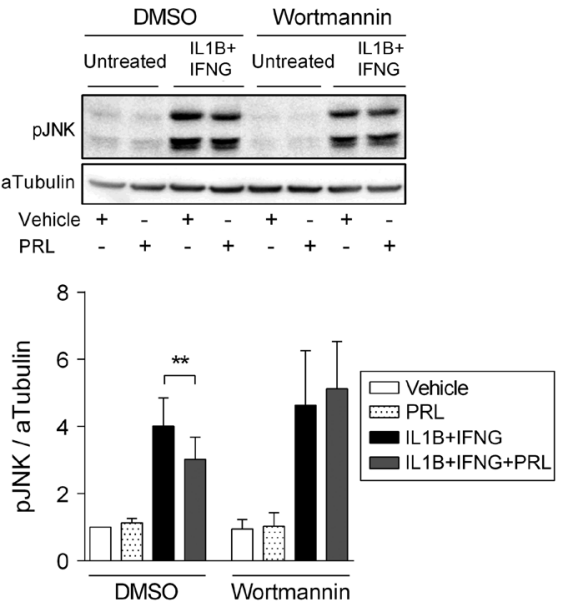

$\mathrm{H}$

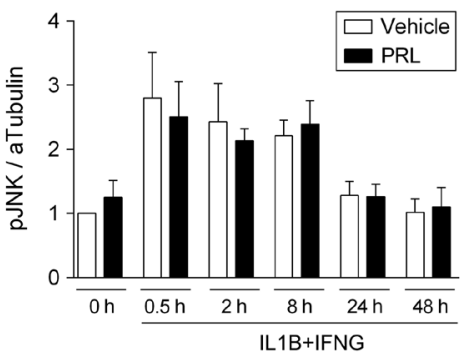

Figure 5

PRL upregulates the phosphorylation of AKT, which contributes for the downregulation of JNK. (A and B) INS-1E cells were treated for $24 \mathrm{~h}$ with PRL or vehicle and then with IL1B + IFNG in the continuous presence of PRL, for the time points indicated in the figure. Protein cell lysates were used in Western blot analysis of (A) phospho-AKT serine (pAKT ser) and (B) threonine (pAKT thr). One representative Western blot of 4 (A) to 5 (B) independent experiments is shown and the optical density measurements of the specific bands corrected by aTubulin and normalized by the control in each experiment (considered as one) are expressed as mean \pm S.E.M. ${ }^{*} P<0.05$ or $* * P<0.01$ for log-transformed paired $t$-test of vehicle vs PRL at each time point. The inset depicts the area under the curve (AUC) for its respective graphs. (C, D and E) INS-1E cells were pretreated for $2 \mathrm{~h}$ with $250 \mathrm{nmol} / \mathrm{L}$ of Wortmannin or DMSO, then treated for $24 \mathrm{~h}$ with PRL or vehicle followed by $8 \mathrm{~h}$ of exposure to IL1B + IFNG in the continuous presence of Wortmannin and PRL. The expression of (C) pAKT ser, (D) pAKT thr and (E) pJNK was assessed by Western blot. One representative Western blot of 5 (C and D) and 5-9 (E) and the optical density measurements of the specific bands corrected by aTubulin and normalized by the control in each experiment (considered as one) are expressed as means \pm S.E.M. $\$ P<0.05$ or $\$ \$ P 0.01$ for log-transformed paired $t$-test of DMSO vs Wortmannin in each condition (C and $D$ ); and $* * P<0.01$ for log-transformed paired $t$-test of vehicle vs PRL $(E) .(F, G$ and $H)$ Isolated rat islets were treated for $24 \mathrm{~h}$ with PRL or vehicle and then with IL1B + IFNG for the time points indicated in the figure and (G) PAKT ser and (H) pJNK were assessed by Western blot. One representative Western blot of 5 independent experiments are shown with the optical density measurements of the specific bands corrected by aTubulin and normalized by the control in each experiment (considered as one) expressed as means \pm S.E.M. ${ }^{*} P \leq 0.05$ for log-transformed paired $t$-test of vehicle vs PRL in each time point. 
is confirmed by the measurement of the area under the curve in each graph (Fig. 5A and B, smaller graph).

AKT is a modulator of JNK activation (Humphrey et al. 2014). We next evaluated whether the observed decrease in cytokine-induced JNK phosphorylation, induced by PRL (Fig. 3A), was caused by AKT activation. INS-1E cells treated with Wortmannin, a PI3K/AKT inhibitor, displayed $\sim 40 \%$ less phosphorylation of both serine and threonine AKT than DMSO treated cells (Fig. 5C and D), and under this condition pre-treatment with PRL failed to decrease cytokine-induced JNK phosphorylation (Fig. 5E). Although PRL was able to promote a small increase in AKT phosphorylation in isolated rat islets exposed to cytokines at $30 \mathrm{~min}$ (Fig. 5F and G), this was not accompanied by modulation of cytokine-induced JNK activation (Fig. 5F and $\mathrm{H})$, at least in the tested conditions.

\section{PRL attenuates the activation of NFKB by cytokines in beta cells}

In parallel to JNK activation, IL1B also induces NFKB activation, a key signal for induction of beta-cell apoptosis (Heimberg et al. 2001, Ortis et al. 2006). We thus assessed the transcriptional activation of $\mathrm{NF \kappa B}$ using a luciferase reporter assay regulated by $6 \mathrm{NF \kappa B}$ binding sites. INS-1E cells treated with IL1B+IFNG presented increased activation of NFkB in a time-dependent manner (Fig. 6A), and pre-treatment with PRL impaired this activation, with a $\sim 40 \%$ decrease after $16 \mathrm{~h}$ of exposure to cytokines (Fig. 6A). These findings were confirmed by analyzing NFkB target genes in beta cells (Fig. 6B, C, D, E and F). Thus, PRL partially prevented cytokine-induction of $I k B a$, Fas, Mcp 1 and $A 20$ by $35-50 \%$ (Fig. 6B, C, D and E) and Cxcl10 by $\sim 70 \%$ (Fig. 6F). Although PRL did not change cytokine-induced iNOS expression in isolated rat islets (Fig. 6G), it decreased this protein in INS-1E cells (Fig. 6H), which was correlated with a decrease in NO production as measure by medium nitrite accumulation (Fig. 6I), and induced a delay in IkBa protein replenishment after its complete degradation by cytokine exposure (Fig. 6J). In rat beta cells, the activation of ER stress is NO dependent (Brozzi et al. 2015); but despite the partial inhibition of NO production (Fig. 6I) PRL did not prevent cytokineinduced ER stress (data not shown).

\section{Discussion}

PRL exerts its anabolic effects on different cell types mainly by stimulating the JAK/STAT pathway. Three members of the STAT family have been identified to promote the activation of the PRL-responsive genes, namely STAT1, STAT3 and STAT5 (DaSilva et al. 1996, Bole-Feysot et al. 1998). STAT5 has been described to be the main mediator of the protective effects of PRL and growth hormone in human and rat beta cells exposed to stressful conditions (Jensen et al. 2005, Terra et al. 2011); while STAT3 has also been suggested to mediate the beneficial effects of PRL on insulin secretion in pancreatic beta cells (Anhe et al. 2007). We presently show that PRL induces STAT3 activation in INS-1E cells, which is related to the observed protective effects of PRL against cytokineinduced apoptosis.

Cytokines induce activation of JNK in rat and human beta cells (Ammendrup et al. 2000, Brozzi et al. 2015). The involvement of JNK in beta-cell death can be dependent (Ortis et al. 2012) or independent of NFkB activation (Gurzov et al. 2008). JNK contributes for the activation of the mitochondrial pathway of apoptosis (Gurzov et al. 2008) through cJUN phosphorylation and Dp5 expression (Gurzov et al. 2009). DP5 inactivates the anti-apoptotic protein BCLxl, leading to the release of PUMA and BIM. These two BH3-only activators induce BAX translocation to the mitochondria, which releases cytochrome $\mathrm{c}$ and triggers the activation of caspases 9 and 3 that execute the intrinsic apoptotic pathway (Gross et al. 1998, 1999). We presently demonstrate that PRL decreases the expression of both cJUN and $D p 5$ and the downstream pro-apoptotic proteins PUMA and BimS, while it increases the antiapoptotic protein BCLxl expression. The net result is a shift from a pro- to an anti-apoptotic balance, which explains the observed protection induced by PRL against cytokine-induced beta-cell death.

In order to clarify the mechanism by which PRL modulates JNK, we assessed the role of AKT kinase in this context. The AKT pathway is an important antiapoptotic signal that inhibits the MAPK cascade involved in cytokine-induced JNK activation (Franke et al. 1997, Humphrey et al. 2014), and we have previously shown that PRL induces PI3K/AKT during pregnancy (Amaral et al. 2004). We presently observed that PRL increases the phosphorylation of AKT and demonstrated that the inhibition of this AKT activation prevent PRL inhibitory effects and even increases cytokine-induced JNK activation. These observations confirm that AKT is one of the signals that mediate the beneficial effects of PRL on beta-cell survival.

$\mathrm{NF \kappa B}$ is an important transcription factor involved in the induction of beta-cell death by cytokines (Giannoukakis et al. 2000, Baker et al. 2001, Heimberg et al. 2001, Ortis et al. 2006). During the activation of NFkB signaling, IkBa 
is rapidly degraded allowing the nuclear translocation of NFkB (Hayden \& Ghosh 2008, Chiu et al. 2009). In the nucleus this transcription factor triggers the transcription of several target genes, including Fas, Mcp1 (Cardozo et al. 2001b, Ortis et al. 2008), Cxcl10 (Cardozo et al. 2003, Eldor et al. 2013), $A 20$ and $I k B a$ (Shembade \& Harhaj 2012). The first three genes are involved in the amplification of the inflammatory process, while $A 20$ and $I k B a$ act as negative regulatory elements retaining $\mathrm{NF \kappa B}$ in the cytoplasm and preventing its translocation to the nucleus (Shembade \& Harhaj 2012). We presently observed that PRL directly reduces the promoter activity of $\mathrm{NFKB}$ after a cytokine stimulus. This is accompanied by attenuation of the pro-inflammatory responses downstream of NF- $\mathrm{kB}$, as evidenced by the observed down regulation of IkBa, Fas, Mcp1, A20 and Cxcl10 expression.
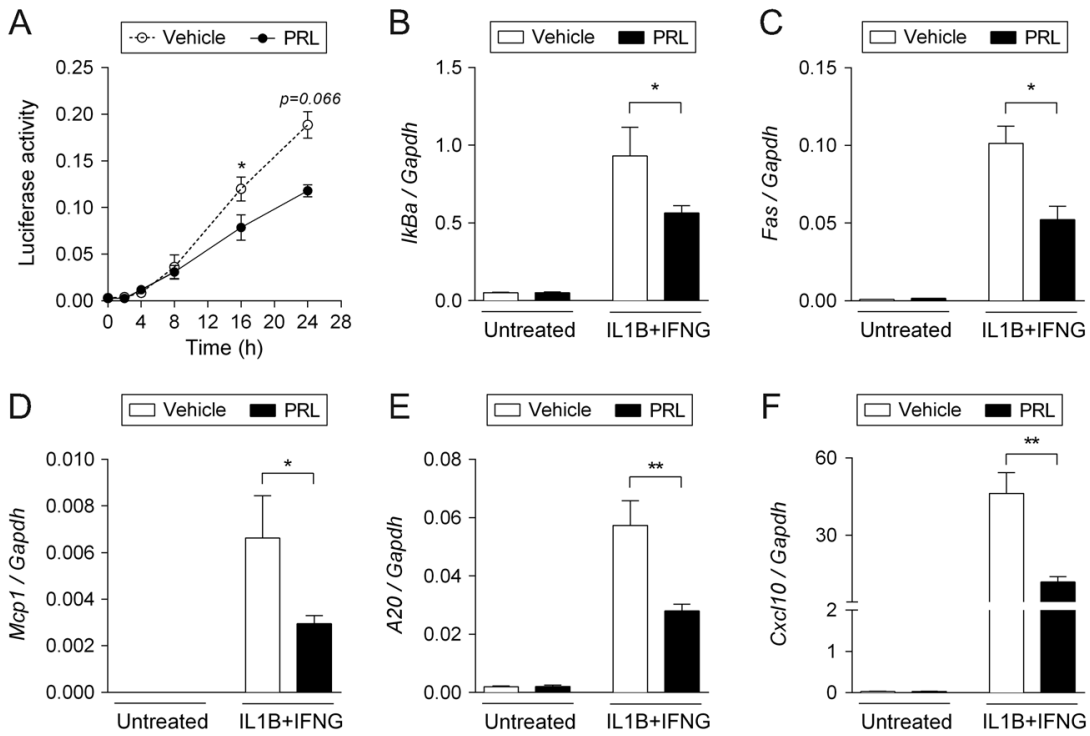

G

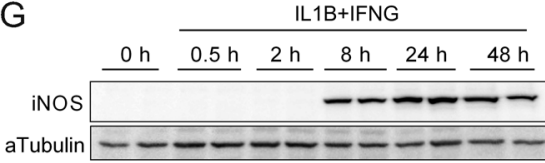

$\mathrm{PRL}-+c_{-}+c_{-}+c_{-}+c_{+}$
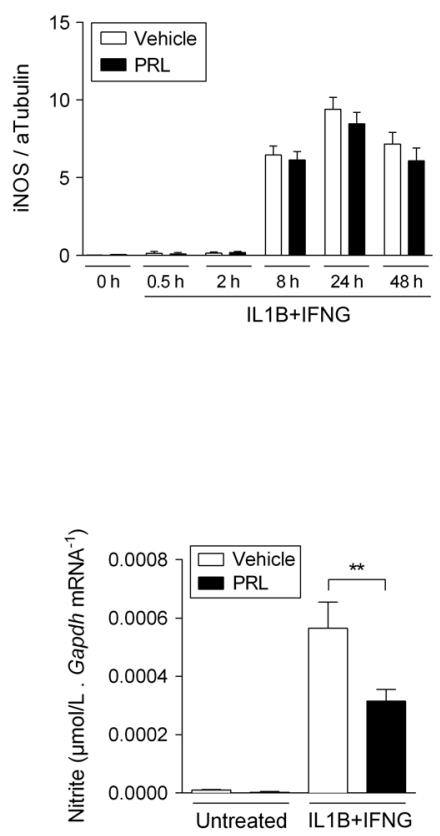

H Untreated IL1B+IFNG

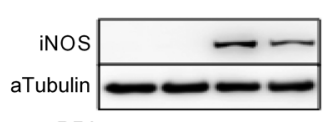

PRL -

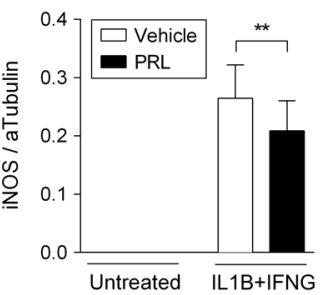

IL1B+IFNG

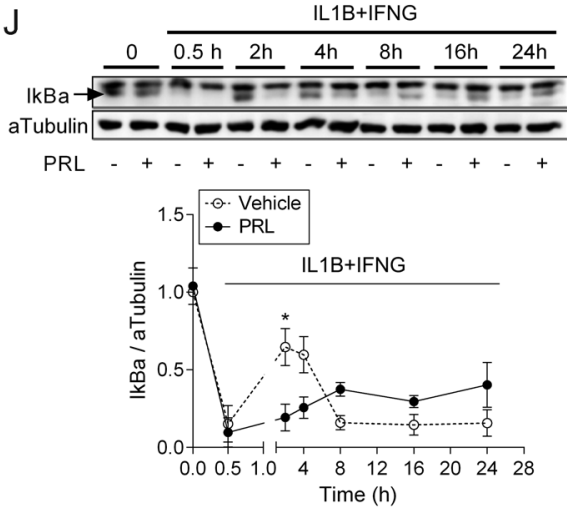

Figure 6

PRL decreases the NFKB activation induced by cytokines. (A) INS-1E cells were transfected for five hours with the NFKB reporter and a pRL-CMV plasmid used as internal control. Sixteen hours after transfection, the cells were pretreated with PRL or vehicle and then with IL1B combined with IFNG for the time points indicated in the figure. Luciferase was assayed, and the obtained values were corrected by the internal control value of each experiment. The results are means \pm S.E.M. of 3 independent experiments. ( $B, C, D, E$ and $F$ ) The expression of the NFKB target genes (B) IkBa, (C) Fas, (D) Mcp1, (E) A20 and (F) Cxcl10 was assessed by qRT-PCR after $24 \mathrm{~h}$ of cytokine treatment and corrected by the housekeeping gene Gapdh. The data represent the means \pm S.E.M. of 4 independent experiments. Expression of (G) iNOS in rat islets $(n=3),(\mathrm{H})$ iNOS $(n=6)$ and $(\mathrm{J}) \mathrm{IkBa}(n=3-4)$ in INS-1E cells were assessed by Western blot analysis at the time points indicated in the figure ( $G$ and $J$ ) and $24 \mathrm{~h}(\mathrm{H})$. One representative Western blot and the optical density measurements of the specific bands corrected by aTubulin are shown. No normalization ( $G$ and $H$ ) or normalization by control was done in each experiment (considered as one) (J). Data are shown as means \pm S.E.M. (I) The supernatant of INS-1E cells treated for $24 \mathrm{~h}$ with vehicle or PRL and then with IL1B + IFNG for additional $24 \mathrm{~h}$ was collected for determination of nitrite accumulation. ${ }^{*} P<0.05$ or $* * P<0.01$ for log-transformed paired $t$-test of vehicle vs PRL at each time point. 
It was previously shown that PRL ameliorates the severity of joint inflammation and reduces chondrocyte apoptosis in models of inflammatory arthritis, possibly via the JAK2/ STAT3-dependent pathway (Adan et al. 2013). These results are consistent with our observation that PRL reduces $\mathrm{NFkB}$ activity and expression of inflammatory mediators. Of note, a constitutively activated form of STAT3 is able to suppress NFkB transcriptional activity (Nishinakamura et al. 2007), while STAT3 knockdown results in significant elevation of NFkB promoter activity (Gong et al. 2014) in other cell types. Therefore, the observed decrease in NFkB activation induced by PRL could be mediated via STAT3 activation, a hypothesis that requires further investigation.

Induction of ER stress by cytokines, via activation of $\mathrm{NF \kappa B}$ and consequently NO production, is involved in the destruction of rat beta cells (Cardozo et al. 2005, Brozzi et al. 2015). Although we observed a decrease in NO production induced by PRL and previous findings demonstrated that pregnancy can improve calcium handling in islets (Vanzela et al. 2010); a condition that can be related to the maintenance of ER homeostasis; here we observed that the protective effects of PRL do not involve the attenuation of the main ER stress signaling pathways that contribute to cytokine-induced beta-cell death (Cardozo et al. 2005).

In conclusion, the present findings suggest that PRL increases the 'apoptosis threshold' in beta cells by both reducing expression/activity of pro-apoptotic effectors and augmenting anti-apoptotic mechanisms. These effects enable beta cells to better survive in face of inflammationinduced stress. Understanding the specific pro-survival proteins and pathways modulated by PRL might provide novel tools to protect beta cells during an autoimmune attack or following islet transplantation.

\section{Declaration of interest}

The authors declare that there is no conflict of interest that could be perceived as prejudicing the impartiality of the research reported.

\section{Funding}

This work was supported by grants from the São Paulo Research Foundation (FAPESP), National Counsel of Technological and Scientific Development (CNPq) and Coordination for the Improvement of Higher Education Personnel (CAPES), Brazil; Juvenile Diabetes Research Foundation International (JDRF); and the Fonds National de la Recherche Scientifique (FNRS), Belgium.

\section{Author contribution statement}

F O, A C B and E C V conceived and supervised the study; F O, T R N and E $C V$ designed the experiments; T R N, E C V, K C B and F B performed the experiments; $D$ L E provided new tools and reagents; TR N, E C V, A F, A K C, D L E, A C B and F O analyzed the data; T R N, E C V, A C B and F O wrote the manuscript; all the authors revised the manuscript.

\section{Acknowledgements}

The authors thank the personnel from the Laboratory of Endocrine Pancreas and Metabolism (UNICAMP) and ULB Center for Diabetes Research: W O Floriano, J P Agulhari, N Pachera, A Musuaya, M Pangerl, $S$ Mertens and I Millard for excellent technical support and the NIDDK's National Hormone \& Peptide Program and A F Parlow.

\section{References}

Adan N, Guzman-Morales J, Ledesma-Colunga MG, Perales-Canales SI, Quintanar-Stephano A, Lopez-Barrera F, Mendez I, MorenoCarranza B, Triebel J, Binart N, et al. 2013 Prolactin promotes cartilage survival and attenuates inflammation in inflammatory arthritis. Journal of Clinical Investigation 123 3902-3913. (https://doi. org/10.1172/JCI69485)

Allagnat F, Cunha D, Moore F, Vanderwinden JM, Eizirik DL \& Cardozo AK 2011 Mcl-1 downregulation by pro-inflammatory cytokines and palmitate is an early event contributing to beta-cell apoptosis. Cell Death and Differentiation 18 328-337. (https://doi. org/10.1038/cdd.2010.105)

Amaral ME, Cunha DA, Anhe GF, Ueno M, Carneiro EM, Velloso LA, Bordin S \& Boschero AC 2004 Participation of prolactin receptors and phosphatidylinositol 3-kinase and MAP kinase pathways in the increase in pancreatic islet mass and sensitivity to glucose during pregnancy. Journal of Endocrinology 183 469-476. (https://doi. org/10.1677/joe.1.05547)

Ammendrup A, Maillard A, Nielsen K, Aabenhus AN, Serup P, Dragsbaek MO, Mandrup-Poulsen T \& Bonny C 2000 The c-Jun aminoterminal kinase pathway is preferentially activated by interleukin-1 and controls apoptosis in differentiating pancreatic beta-cells. Diabetes 49 1468-1476. (https://doi.org/10.2337/diabetes.49.9.1468)

Anhe GF, Nogueira TC, Nicoletti-Carvalho JE, Lellis-Santos C, Barbosa HC, Cipolla-Neto J, Bosqueiro JR, Boschero AC \& Bordin S 2007 Signal transducer and activator of transcription 3-regulated sarcoendoplasmic reticulum Ca2+-ATPase 2 expression by prolactin and glucocorticoids is involved in the adaptation of insulin secretory response during the peripartum period. Journal of Endocrinology 195 17-27. (https://doi.org/10.1677/JOE-07-0010)

Asfari M, Janjic D, Meda P, Li G, Halban PA \& Wollheim CB 1992 Establishment of 2-mercaptoethanol-dependent differentiated insulin-secreting cell lines. Endocrinology 130 167-178. (https://doi. org/10.1210/endo.130.1.1370150)

Baker MS, Chen X, Cao XC \& Kaufman DB 2001 Expression of a dominant negative inhibitor of NF-kappaB protects MIN6 beta-cells from cytokine-induced apoptosis. Journal of Surgical Research 97 117-122. (https://doi.org/10.1006/jsre.2001.6121)

Bole-Feysot C, Goffin V, Edery M, Binart N \& Kelly PA 1998 Prolactin (PRL) and its receptor: actions, signal transduction pathways and phenotypes observed in PRL receptor knockout mice. Endocrine Reviews 19 225-268. (https://doi.org/10.1210/edrv.19.3.0334)

Bordin S, Amaral ME, Anhe GF, Delghingaro-Augusto V, Cunha DA, Nicoletti-Carvalho JE \& Boschero AC 2004 Prolactin-modulated gene expression profiles in pancreatic islets from adult female rats. Molecular and Cellular Endocrinology 220 41-50. (https://doi. org/10.1016/j.mce.2004.04.001)

Boschero AC, Crepaldi SC, Carneiro EM, Delattre E \& Atwater I 1993 Prolactin induces maturation of glucose sensing mechanisms in cultured neonatal rat islets. Endocrinology 133 515-520. (https://doi. org/10.1210/endo.133.2.8344197)

Brozzi F, Nardelli TR, Lopes M, Millard I, Barthson J, Igoillo-Esteve M, Grieco FA, Villate O, Oliveira JM, Casimir M, et al. 2015 Cytokines induce endoplasmic reticulum stress in human, rat and mouse beta cells via different mechanisms. Diabetologia 58 2307-2316. (https:// doi.org/10.1007/s00125-015-3669-6) 
Cardozo AK, Heimberg H, Heremans Y, Leeman R, Kutlu B, Kruhoffer M, Orntoft T \& Eizirik DL 2001a A comprehensive analysis of cytokineinduced and nuclear factor-kappa B-dependent genes in primary rat pancreatic beta-cells. Journal of Biological Chemistry 276 48879-48886. (https://doi.org/10.1074/jbc.M108658200)

Cardozo AK, Kruhoffer M, Leeman R, Orntoft T \& Eizirik DL $2001 b$ Identification of novel cytokine-induced genes in pancreatic betacells by high-density oligonucleotide arrays. Diabetes 50 909-920. (https://doi.org/10.2337/diabetes.50.5.909)

Cardozo AK, Proost P, Gysemans C, Chen MC, Mathieu C \& Eizirik DL 2003 IL-1beta and IFN-gamma induce the expression of diverse chemokines and IL-15 in human and rat pancreatic islet cells, and in islets from pre-diabetic NOD mice. Diabetologia 46 255-266. (https:// doi.org/10.1007/s00125-002-1017-0)

Cardozo AK, Ortis F, Storling J, Feng YM, Rasschaert J, Tonnesen M, Van EF, Mandrup-Poulsen T, Herchuelz A \& Eizirik DL 2005 Cytokines downregulate the sarcoendoplasmic reticulum pump Ca2+ ATPase $2 \mathrm{~b}$ and deplete endoplasmic reticulum $\mathrm{Ca} 2+$, leading to induction of endoplasmic reticulum stress in pancreatic beta-cells. Diabetes 54 452-461. (https://doi.org/10.2337/diabetes.54.2.452)

Chiu YH, Zhao M \& Chen ZJ 2009 Ubiquitin in NF-kappaB signaling. Chemical Reviews 109 1549-1560. (https://doi.org/10.1021/ cr800554j)

Crepaldi SC, Carneiro EM \& Boschero AC 1997 Long-term effect of prolactin treatment on glucose-induced insulin secretion in cultured neonatal rat islets. Hormone and Metabolic Research 29 220-224. (https://doi.org/10.1055/s-2007-979025)

Cunha DA, Roma LP \& Boschero AC 2007 Prolactin modulates the association and phosphorylation of SNARE and kinesin/MAP-2 proteins in neonatal pancreatic rat islets. Molecular and Cellular Endocrinology 273 32-41. (https://doi.org/10.1016/j.mce.2007.05.001)

Darville MI, Terryn S \& Eizirik DL 2004 An octamer motif is required for activation of the inducible nitric oxide synthase promoter in pancreatic beta-cells. Endocrinology 145 1130-1136. (https://doi. org/10.1210/en.2003-1200)

DaSilva L, Rui H, Erwin RA, Howard OM, Kirken RA, Malabarba MG Hackett RH, Larner AC \& Farrar WL 1996 Prolactin recruits STAT1, STAT3 and STAT5 independent of conserved receptor tyrosines TYR402, TYR479, TYR515 and TYR580. Molecular and Cellular Endocrinology 117 131-140. (https://doi.org/10.1016/03037207(95)03738-1)

Eldor R, Abel R, Sever D, Sadoun G, Peled A, Sionov R \& Melloul D 2013 Inhibition of nuclear factor-kappaB activation in pancreatic betacells has a protective effect on allogeneic pancreatic islet graft survival. PLoS ONE 8 e56924. (https://doi.org/10.1371/journal. pone.0056924)

Franke TF, Kaplan DR \& Cantley LC 1997 PI3K: downstream AKTion blocks apoptosis. Cell 88 435-437. (https://doi.org/10.1016/S00928674(00)81883-8)

Giannoukakis N, Rudert WA, Trucco M \& Robbins PD 2000 Protection of human islets from the effects of interleukin-1beta by adenoviral gene transfer of an Ikappa B repressor. Journal of Biological Chemistry 275 36509-36513. (https://doi.org/10.1074/jbc.M005943200)

Gong J, Xie J, Bedolla R, Rivas P, Chakravarthy D, Freeman JW, Reddick R, Kopetz S, Peterson A, Wang H, et al. 2014 Combined targeting of STAT3/NF-kappaB/COX-2/EP4 for effective management of pancreatic cancer. Clinical Cancer Research 20 1259-1273. (https:// doi.org/10.1158/1078-0432.CCR-13-1664)

Green LC, Wagner DA, Glogowski J, Skipper PL, Wishnok JS \& Tannenbaum SR 1982 Analysis of nitrate, nitrite, and [15N]nitrate in biological fluids. Analytical Biochemistry 126 131-138. (https://doi. org/10.1016/0003-2697(82)90118-X)

Gross A, Jockel J, Wei MC \& Korsmeyer SJ 1998 Enforced dimerization of BAX results in its translocation, mitochondrial dysfunction and apoptosis. EMBO Journal 17 3878-3885. (https://doi.org/10.1093/ emboj/17.14.3878)
Gross A, Yin XM, Wang K, Wei MC, Jockel J, Milliman C, ErdjumentBromage H, Tempst P \& Korsmeyer SJ 1999 Caspase cleaved BID targets mitochondria and is required for cytochrome c release, while BCL-XL prevents this release but not tumor necrosis factor-R1/Fas death. Journal of Biological Chemistry 274 1156-1163. (https://doi. org/10.1074/jbc.274.2.1156)

Gurzov EN \& Eizirik DL 2011 Bcl-2 proteins in diabetes: mitochondrial pathways of beta-cell death and dysfunction. Trends in Cell Biology 21 424-431. (https://doi.org/10.1016/j.tcb.2011.03.001)

Gurzov EN, Ortis F, Bakiri L, Wagner EF \& Eizirik DL 2008 JunB inhibits ER stress and apoptosis in pancreatic beta cells. PLOS ONE 3 e3030. (https://doi.org/10.1371/journal.pone.0003030)

Gurzov EN, Ortis F, Cunha DA, Gosset G, Li M, Cardozo AK \& Eizirik DL 2009 Signaling by IL-1beta+IFN-gamma and ER stress converge on DP5/Hrk activation: a novel mechanism for pancreatic beta-cell apoptosis. Cell Death and Differentiation 16 1539-1550. (https://doi. org/10.1038/cdd.2009.99)

Hayden MS \& Ghosh S 2008 Shared principles in NF-kappaB signaling. Cell 132 344-362. (https://doi.org/10.1016/j.cell.2008.01.020)

Heimberg H, Heremans Y, Jobin C, Leemans R, Cardozo AK, Darville M \& Eizirik DL 2001 Inhibition of cytokine-induced NF-kappaB activation by adenovirus-mediated expression of a NF-kappaB superrepressor prevents beta-cell apoptosis. Diabetes 50 2219-2224. (https://doi.org/10.2337/diabetes.50.10.2219)

Humphrey RK, Ray A, Gonuguntla S, Hao E \& Jhala US 2014 Loss of TRB3 alters dynamics of MLK3-JNK signaling and inhibits cytokineactivated pancreatic beta cell death. Journal of Biological Chemistry 289 29994-30004. (https://doi.org/10.1074/jbc.M114.575613)

Janjic D, Maechler P, Sekine N, Bartley C, Annen AS \& Wolheim CB 1999 Free radical modulation of insulin release in INS-1 cells exposed to alloxan. Biochemical Pharmacology 57 639-648. (https:// doi.org/10.1016/S0006-2952(98)00346-3)

Jensen J, Galsgaard ED, Karlsen AE, Lee YC \& Nielsen JH 2005 STAT5 activation by human $\mathrm{GH}$ protects insulin-producing cells against interleukin-1beta, interferon-gamma and tumour necrosis factor-alphainduced apoptosis independent of nitric oxide production. Journal of Endocrinology 187 25-36. (https://doi.org/10.1677/joe.1.06086)

Kim H, Rafiuddin-Shah M, Tu HC, Jeffers JR, Zambetti GP, Hsieh JJ \& Cheng EH 2006 Hierarchical regulation of mitochondrion-dependent apoptosis by BCL-2 subfamilies. Nature Cell Biology 8 1348-1358. (https://doi.org/10.1038/ncb1499)

Kukreja A \& Maclaren NK 1999 Autoimmunity and diabetes. Journal of Clinical Endocrinology and Metabolism 84 4371-4378. (https://doi. $\operatorname{org} / 10.1210 /$ jcem.84.12.6212)

Kutlu B, Cardozo AK, Darville MI, Kruhoffer M, Magnusson N, Orntoft T \& Eizirik DL 2003 Discovery of gene networks regulating cytokineinduced dysfunction and apoptosis in insulin-producing INS-1 cells. Diabetes 52 2701-2719. (https://doi.org/10.2337/diabetes.52.11.2701)

Nishinakamura H, Minoda Y, Saeki K, Koga K, Takaesu G, Onodera M, Yoshimura A \& Kobayashi T 2007 An RNA-binding protein alphaCP-1 is involved in the STAT3-mediated suppression of NF-kappaB transcriptional activity. International Immunology 19 609-619. (https://doi.org/10.1093/intimm/dxm026)

Noble JA 2015 Immunogenetics of type 1 diabetes: a comprehensive review. Journal of Autoimmunity 64 101-112. (https://doi. org/10.1016/j.jaut.2015.07.014)

Ortis F, Cardozo AK, Crispim D, Storling J, Mandrup-Poulsen T \& Eizirik DL 2006 Cytokine-induced proapoptotic gene expression in insulin-producing cells is related to rapid, sustained, and nonoscillatory nuclear factor-kappaB activation. Molecular Endocrinology 20 1867-1879. (https://doi.org/10.1210/me.2005-0268)

Ortis F, Pirot P, Naamane N, Kreins AY, Rasschaert J, Moore F, Theatre E, Verhaeghe C, Magnusson NE, Chariot A, et al. 2008 Induction of nuclear factor-kappaB and its downstream genes by TNF-alpha and IL-1beta has a pro-apoptotic role in pancreatic beta cells. Diabetologia 51 1213-1225. (https://doi.org/10.1007/s00125-008-0999-7) 
Ortis F, Naamane N, Flamez D, Ladriere L, Moore F, Cunha DA, Colli ML, Thykjaer T, Thorsen K, Orntoft TF, et al. 2010 Cytokines interleukin-1beta and tumor necrosis factor-alpha regulate different transcriptional and alternative splicing networks in primary beta-cells. Diabetes 59 358-374. (https://doi.org/10.2337/ db09-1159)

Ortis F, Miani M, Colli ML, Cunha DA, Gurzov EN, Allagnat F, Chariot A \& Eizirik DL 2012 Differential usage of NF-kappaB activating signals by IL-1beta and TNF-alpha in pancreatic beta cells. FEBS Letters $\mathbf{5 8 6}$ 984-989. (https://doi.org/10.1016/j.febslet.2012.02.021)

Schulz K, Kerber S \& Kelm M 1999 Reevaluation of the Griess method for determining NO/NO2- in aqueous and protein-containing samples. Nitric Oxide 3 225-234. (https://doi.org/10.1006/ niox.1999.0226)

Shembade N \& Harhaj EW 2012 Regulation of NF-kappaB signaling by the A20 deubiquitinase. Cellular and Molecular Immunology 9 123-130. (https://doi.org/10.1038/cmi.2011.59)

Storling J, Binzer J, Andersson AK, Zullig RA, Tonnesen M, Lehmann R, Spinas GA, Sandler S, Billestrup N \& Mandrup-Poulsen T 2005 Nitric oxide contributes to cytokine-induced apoptosis in pancreatic beta cells via potentiation of JNK activity and inhibition of Akt. Diabetologia 48 2039-2050. (https://doi.org/10.1007/s00125-0051912-2)

Terra LF, Garay-Malpartida MH, Wailemann RA, Sogayar MC \& Labriola L 2011 Recombinant human prolactin promotes human beta cell survival via inhibition of extrinsic and intrinsic apoptosis pathways. Diabetologia 54 1388-1397. (https://doi.org/10.1007/ s00125-011-2102-z)

Vanzela EC, Ribeiro RA, de Oliveira CA, Rodrigues FB, Bonfleur ML, Carneiro EM, Souza KL \& Boschero AC 2010 Pregnancy restores insulin secretion from pancreatic islets in cafeteria diet-induced obese rats. American Journal of Physiology: Regulatory Integrative and Comparative Physiology 298 R320-R328. (https://doi.org/10.1152/ ajpregu.00256.2009)

Vermeulen L, De WG, Notebaert S, Vanden Berghe W \& Haegeman G 2002 Regulation of the transcriptional activity of the nuclear factorkappaB p65 subunit. Biochemical Pharmacology 64 963-970. (https:// doi.org/10.1016/S0006-2952(02)01161-9)

Received in final form 20 March 2018

Accepted 9 April 2018

Accepted Preprint published online 9 April 2018 